\title{
Genetic Disorders With Symptoms Mimicking Rheumatologic Diseases
}

\author{
Ummusen Kaya Akca \\ Hacettepe Universitesi Tip Fakultesi \\ Pelin Ozlem Simsek Kiper \\ Hacettepe Universitesi Tip Fakultesi \\ Gizem Urel Demir \\ Hacettepe Universitesi Tip Fakultesi \\ Erdal Sag \\ Hacettepe Universitesi Tip Fakultesi \\ Erdal Atalay \\ Hacettepe Universitesi Tip Fakultesi \\ Gulen Eda Utine \\ Hacettepe Universitesi Tip Fakultesi \\ Mehmet Alikasifoglu \\ Hacettepe Universitesi Tip Fakultesi \\ Koray Boduroglu \\ Hacettepe Universitesi Tip Fakultesi \\ Yelda Bilginer \\ Hacettepe Universitesi Tip Fakultesi \\ Seza Özen ( $\nabla$ sezaozen@gmail.com ) \\ Hacettepe University https://orcid.org/0000-0003-2883-7868
}

Research article

Keywords: genetic disorders, musculoskeletal symptoms, genetic syndromes

Posted Date: August 10th, 2020

DOI: https://doi.org/10.21203/rs.3.rs-55736/v1

License: (9) (7) This work is licensed under a Creative Commons Attribution 4.0 International License. Read Full License 


\section{Abstract}

\section{Background}

Musculoskeletal symptoms may be due to non-inflammatory causes including genetic disorders. We aimed to examine the final genetic diagnosis in patients who had presented with musculoskeletal complaints to rheumatology department.

\section{Methods}

Patients presenting to the department of pediatric rheumatology and consulted to the genetic department between January 2015 and May 2019 were evaluated retrospectively.

\section{Results}

A total of 60 patients, 19 boys (31.66\%), with a mean age $12.46 \pm 1.41$ years were included in the study. Total consanguinity rate was $25 \%$. The most common $(29.5 \%)$ cause of referral to the genetic department was the presence of skeletal anomalies (such as camptodactyly, clinodactyly, and short stature) with accompanying joint findings. Approximately one third of the patients ( $\mathrm{n}$ : 19) were diagnosed and followed up by the genetic department. The diagnoses of patients were as follows; CACP syndrome (n:3), trichorhinophalangeal syndrome (n:1), progressive pseudoromatoid dysplasia (n:2), LIG4 syndrome (n:1), H syndrome (n:1), SPENCD syndrome (n:3), and nonspecific connective tissue disease (n:8).

\section{Conclusions}

In the differential diagnosis of patients who are referred to the department of pediatric rheumatology with complaints of the musculoskeletal system, genetic disorders should also be taken into consideration.

Clinical Trial Registration: Hacettepe University Ethics Commission (Approval number: G0 19/781)

\section{Background}

Musculoskeletal complaints may be the initial presenting symptoms in a number of genetic diseases (1). Musculoskeletal system symptoms may occur as part of genetic syndromes or genetic skeletal disorders that affect the development and growth of cartilage or bone. Patients with genetic skeletal disorders may present with disproportionate short stature, scoliosis, extremity anomalies (such as curvature in long tubular bones, brachydactyly, camptodactyly, limb asymmetry) or recurrent joint dislocation (2). Progressive pseudo rheumatoid dysplasia (PPRD) and CACP syndrome (camptodactyly, arthropathy, coxa vara deformity and pericarditis) can mimic juvenile idiopathic arthritis $(3,4)$. Correct diagnosis is often delayed in these patients $(5)$. The absence of signs of inflammation (morning stiffness, redness, tenderness) and normal (laboratory) inflammatory markers may suggest non-rheumatologic diseases (6). A detailed history of symptoms, family history, a pedigree of at least three generations, a systemic examination including anthropometric measurements, laboratory tests and radiologic examination are required to identify such genetic disorders (7). Accurate diagnosis of genetic disorders also helps in predicting the natural course and prognosis of the disease, providing proper genetic counseling and avoidance of unnecessary treatment.

We aimed to present our single center experience with genetic disorders mimicking rheumatic diseases with similar symptoms. We hope these cases will raise awareness for these genetic disorders, in the differential for our common diseases.

\section{Methods}

This study includes retrospective analysis of 60 patients who were admitted to our department of pediatric rheumatology with musculoskeletal complaints considered not to be associated with rheumatic diseases between January 2015 and December 2019; these patients were consulted to genetics department. Patients who were evaluated and diagnosed by another genetic center were not included in the study. The rate and degree of consanguinity, clinical diagnosis, indication for consultation, accompanying musculoskeletal and other findings were all recorded. Anthropometric measurements (height and weight) were obtained using percentile values of Turkish children (8). Short stature was defined as the height that is 2 standard deviations (SD) or more below the mean for children of that sex and chronologic age. The diagnosis of genetic disorders were primarily based on a detailed history including family history, pregnancy history, neonatal history, developmental milestones and current schooling provision, physical examination including dysmorphology examination and assessment of behavioural phenotype, radiological evaluations when necessary and genetic analysis. "Definite clinical and molecular diagnosis" were established by means of history, physical examination, radiologic assessments and genetic analysis whenever available. Patients in whom no genetic etiology could be revealed but the diagnosis was made on clinical and radiological grounds were defined as "definite clinical diagnosis", and patients diagnosed with only clinical findings were defined as "strongly probable diagnosis" (9).

Ethical approval for this study was obtained (Project No: GO 19/781). Written informed consent was given from patients or their parents for publication of genetic analysis results. Statistical analyses were performed by using the SPSS version 20 package. Descriptive statistics were presented as frequency, percentage, mean, SD and median values.

\section{Results}

A total of 60 patients, 19 boys (31.6\%), with a mean age of $12.46 \pm 1.41$ years were included in the study. The rate of consanguinity was $25.0 \%$. Parental first cousin marriage and $\geq 2$ nd cousin marriages were detected in $10(16.6 \%)$ and $5(8.3 \%)$ families, respectively. The reasons for admission to the rheumatology Loading [MathJax]/jax/output/CommonHTML/jax.js ; follows; joint swelling $(n=15 / 60,25.0 \%)$, extremity deformity $(n=12 / 60,20.0 \%)$, arthralgia $(n=11 / 60,18.3 \%)$, 
skin rash $(n=9 / 60,15.0 \%)$, abdominal pain and fever $(n=4 / 60,6.6 \%)$, Raynaud syndrome $(n=3 / 60,5.0 \%)$ and other reasons (oral aphthous ulcers, edema, dry mouth and dry eye) in $6(10.0 \%)$ patients.

The most frequent $(n=12 / 60,20 \%)$ reason for referral to the genetic department was the presence of skeletal anomalies such as camptodactyly, clinodactyly, and shortness in tubular bones accompanying joint findings. Other causes in decreasing frequency were as follows; accompanying findings such as neurocutaneous findings and family history that are suggestive of a genetic syndrome $(n=11 / 60,18.3 \%)$, joint hyperlaxity $(n=10 / 60,16.6 \%)$, dysmorphic facial features $(n=9 / 60,15 \%)$, joint deformity $(n=5 / 60,8.3 \%)$, other joint findings without clinical and laboratory signs of inflammation $(n=5 / 60,8.3 \%)$, short stature $(n=4 / 60,6.6 \%)$, and abnormal radiological findings suggestive of a genetic disorder $(n=4 / 60,6.6 \%)$.

The most commonly affected joints in all patients, in general, were hands, knees and spine (Fig. 1) whereas in 19 patients with a genetic disorder, the most commonly affected joints were hands, knees, and hips.

In the laboratory evaluation of patients presenting with joint swelling and arthralgia, acute phase reactants including erythrocyte sedimentation rate and Creactive protein concentrations were all within normal laboratory reference values.

Among these 60 patients, $19(n=19 / 60,31.6 \%)$ had a final diagnosis of a genetic disorder. The diagnoses in decreasing frequency were as follows; nonspecific connective tissue disease (n:8), CACP syndrome (n:3), SPENCD (n:3), progressive pseudoromatoid dysplasia ( $\mathrm{n}: 2)$, trichorhinophalangeal syndrome (n:1), LIG4 syndrome (n:1), and H syndrome (n:1). Parental consanguinity was present in $25 \%$ of patients. The rate was similar among patients with a genetic disorder (25.0\% vs $25.0 \%)$. Among the patients with genetic diagnosis $(n=19)$, six patients $(31.5 \%)$ had a definite clinical and molecular diagnosis while five patients (26.3\%) had definite clinical diagnosis. Clinical features of patients with definitive clinical and molecular diagnosis and definite clinical diagnosis are shown in Table 1. 
Table 1

Clinicinal, radiological and moleculer features of patients with "definite clinical and molecular diagnosis" and "definite molecular diagno

\begin{tabular}{|c|c|c|c|c|c|c|c|c|c|}
\hline $\begin{array}{l}\text { Patient } \\
\text { no }\end{array}$ & Gender & $\begin{array}{l}\text { Age } \\
\text { at } \\
\text { diagnosis }\end{array}$ & $\begin{array}{l}\text { History of } \\
\text { consanguinity } \\
\text { of families } \\
\text { (Degree of } \\
\text { consanguinity) }\end{array}$ & $\begin{array}{l}\text { Reason for } \\
\text { application to } \\
\text { rheumatology } \\
\text { department }\end{array}$ & $\begin{array}{l}\text { Consultation } \\
\text { indication }\end{array}$ & $\begin{array}{l}\text { Physical examination } \\
\text { findings }\end{array}$ & $\begin{array}{l}\text { Radiologic specific } \\
\text { findings }\end{array}$ & $\begin{array}{l}\text { Diagnosis } \\
\text { grouping }\end{array}$ & $\begin{array}{l}N \\
\mathbf{d} i\end{array}$ \\
\hline 1 & Girl & 5 & $\begin{array}{l}\text { Yes } \\
\text { (1st degree } \\
\text { cousin } \\
\text { marriages) }\end{array}$ & $\begin{array}{l}\text { Swelling of } \\
\text { joints }\end{array}$ & $\begin{array}{l}\text { Camptodactyly, } \\
\text { arthritis }\end{array}$ & $\begin{array}{l}\text { Restriction in the right } \\
\text { elbow and both } \\
\text { wrists, swelling in } \\
\text { both hands and knee } \\
\text { joints, camptodactyly } \\
\text { in } 2 \text { nd and 3rd fingers } \\
\text { of both hands, limited } \\
\text { abduction of the right } \\
\text { hip }\end{array}$ & $\begin{array}{l}\text { Camptodactyly in the } \\
\text { hands }\end{array}$ & $\begin{array}{l}\text { Definite } \\
\text { clinical } \\
\text { and } \\
\text { molecular } \\
\text { diagnosis }\end{array}$ & $\begin{array}{l}\mathrm{H} \\
P \\
\mathrm{~m}\end{array}$ \\
\hline 2 & Girl & 12 & $\begin{array}{l}\text { No (originated } \\
\text { from same } \\
\text { village) }\end{array}$ & $\begin{array}{l}\text { Swelling of } \\
\text { joints }\end{array}$ & $\begin{array}{l}\text { Camptodactyly, } \\
\text { clinodactyly, } \\
\text { arthritis }\end{array}$ & $\begin{array}{l}\text { Extension limitation } \\
\text { in bilateral elbow } \\
\text { joints, camptodactyly } \\
\text { in the thumbs of both } \\
\text { hands, joint swelling } \\
\text { in the elbows, knees, } \\
\text { and left hip restriction }\end{array}$ & $\begin{array}{l}\text { Camptodactyly in the } \\
\text { hands, }\end{array}$ & $\begin{array}{l}\text { Definite } \\
\text { clinical } \\
\text { and } \\
\text { molecular } \\
\text { diagnosis }\end{array}$ & $\begin{array}{l}\mathrm{H} \\
P \\
\mathrm{~m}\end{array}$ \\
\hline 3 & Boy & 9 & No & $\begin{array}{l}\text { Swelling of } \\
\text { joints }\end{array}$ & $\begin{array}{l}\text { Curvature and } \\
\text { joint swelling in } \\
\text { the fingers, } \\
\text { taken treatment } \\
\text { as a JIA patient } \\
\text { but did not } \\
\text { benefit from it }\end{array}$ & $\begin{array}{l}\text { Extension restriction } \\
\text { in the joints of the } \\
\text { hand, camptodactyly } \\
\text { in 3rd, 4th and } 5 \text { th } \\
\text { fingers of right hand }\end{array}$ & $\begin{array}{l}\text { Camptodactyly in the } \\
\text { hands }\end{array}$ & $\begin{array}{l}\text { Definite } \\
\text { molecular } \\
\text { diagnosis }\end{array}$ & $\begin{array}{l}\mathrm{N} \\
\mathrm{m}\end{array}$ \\
\hline 4 & Girl & 12 & No & $\begin{array}{l}\text { Curvature of } \\
\text { her fingers }\end{array}$ & $\begin{array}{l}\text { Camptodactyly } \\
\text { and facial } \\
\text { findings }\end{array}$ & $\begin{array}{l}\text { Clinodactyly in } 2 \text { nd, } \\
\text { 3rd, 4th fingers of } \\
\text { right hand and middle } \\
\text { finger of the left } \\
\text { hand. } \\
\text { Short structure, } \\
\text { prominent nose tip, } \\
\text { thin upper lip, and } \\
\text { sparse hair. }\end{array}$ & $\begin{array}{l}\text { On hand MRI } \\
\text { imaging, epiphyseal } \\
\text { irregularities in the } \\
\text { PIF joint faces of } \\
\text { middle phalanges, } \\
\text { deformities, and } \\
\text { shortness of the 4th } \\
\text { and 5th metacarpes } \\
\text { of the right hand }\end{array}$ & $\begin{array}{l}\text { Definite } \\
\text { molecular } \\
\text { diagnosis }\end{array}$ & $\begin{array}{l}\mathrm{N} \\
\text { in } \\
\mathrm{FI} \\
\text { al }\end{array}$ \\
\hline 5 & Girl & 12 & No & $\begin{array}{l}\text { Swelling of } \\
\text { joints for two } \\
\text { years }\end{array}$ & $\begin{array}{l}\text { Polyarticular } \\
\text { involvement } \\
\text { without } \\
\text { arthralgia and } \\
\text { normal acute } \\
\text { phase reactants } \\
\text { response }\end{array}$ & $\begin{array}{l}\text { Swelling and } \\
\text { enlargement in } \\
\text { proximal } \\
\text { interphalangeal } \\
\text { joints of 2-5th fingers } \\
\text { on right hand }\end{array}$ & $\begin{array}{l}\text { Epiphyseal } \\
\text { enlargement of the } \\
\text { metacarpophalangeal } \\
\text { and interphalangeal } \\
\text { joints }\end{array}$ & $\begin{array}{l}\text { Definite } \\
\text { molecular } \\
\text { diagnosis }\end{array}$ & $\begin{array}{l}\mathrm{N} \\
\mathrm{m}\end{array}$ \\
\hline 6 & Boy & 16 & $\begin{array}{l}\text { Yes } \\
\text { (1st degree } \\
\text { cousin } \\
\text { marriages) }\end{array}$ & $\begin{array}{l}\text { Hip and low } \\
\text { back pain }\end{array}$ & $\begin{array}{l}\text { Compatible } \\
\text { findings with } \\
\text { PPRD in } \\
\text { thoracolumbar } \\
\text { MRI }\end{array}$ & $\begin{array}{l}\text { Low back pain and } \\
\text { swelling of knee and } \\
\text { elbow joints }\end{array}$ & $\begin{array}{l}\text { In radiological } \\
\text { examination of the } \\
\text { spine, platyspondyly } \\
\text { of vertebral bodies, } \\
\text { anterior wedging of } \\
\text { vertebrae, and erosion } \\
\text { in the end plates. } \\
\text { Enlarged epiphyses } \\
\text { of the femoral heads. }\end{array}$ & $\begin{array}{l}\text { Definite } \\
\text { molecular } \\
\text { diagnosis }\end{array}$ & $\begin{array}{l}\mathrm{N} \\
\mathrm{m}\end{array}$ \\
\hline 7 & Boy & 19 & $\begin{array}{l}\text { Yes } \\
\text { (2nd degree } \\
\text { cousin } \\
\text { marriages) }\end{array}$ & $\begin{array}{l}\text { Joint } \\
\text { swelling, oral } \\
\text { and genital } \\
\text { aphthae }\end{array}$ & $\begin{array}{l}\text { Accompanying } \\
\text { diseases } \\
\text { (hypothyroidism, } \\
\text { growth hormone } \\
\text { deficiency, } \\
\text { recurrent } \\
\text { meningitis and } \\
\text { respiratory } \\
\text { problems, and } \\
\text { developmental } \\
\text { delay) }\end{array}$ & $\begin{array}{l}\text { Short stature, normal } \\
\text { joint examination }\end{array}$ & - & $\begin{array}{l}\text { Definite } \\
\text { clinical } \\
\text { and } \\
\text { molecular } \\
\text { diagnosis }\end{array}$ & $\begin{array}{l}L \\
\mathrm{~m}\end{array}$ \\
\hline 8 & Girl & 14 & $\begin{array}{l}\text { Yes } \\
\text { (1st degree } \\
\text { cousin } \\
\text { marriages) }\end{array}$ & $\begin{array}{l}\text { Limited joint } \\
\text { range of } \\
\text { motion }\end{array}$ & $\begin{array}{l}\text { Accompanying } \\
\text { diseases } \\
\text { (hyperpigmented } \\
\text { lesions, } \\
\text { diagnosis of tip1 } \\
\text { diabetes } \\
\text { mellitus, short } \\
\text { stature and } \\
\text { signs of } \\
\text { hypogonadism) }\end{array}$ & $\begin{array}{l}\text { Short stature, purple- } \\
\text { black colored } \\
\text { hyperpigmented } \\
\text { lesions which were } \\
\text { more prominent on } \\
\text { the legs, contracture } \\
\text { in the proximal in } \\
\text { interphalangeal joints } \\
\text { of bilateral hands }\end{array}$ & - & $\begin{array}{l}\text { Definite } \\
\text { clinical } \\
\text { and } \\
\text { molecular } \\
\text { diagnosis }\end{array}$ & $\begin{array}{l}\mathrm{H} \\
\mathrm{d} \\
\text { e) } \\
\mathrm{S}\end{array}$ \\
\hline
\end{tabular}




\begin{tabular}{|c|c|c|c|c|c|c|c|c|c|}
\hline $\begin{array}{l}\text { Patient } \\
\text { no }\end{array}$ & Gender & $\begin{array}{l}\text { Age } \\
\text { at } \\
\text { diagnosis }\end{array}$ & $\begin{array}{l}\text { History of } \\
\text { consanguinity } \\
\text { of families } \\
\text { (Degree of } \\
\text { consanguinity) }\end{array}$ & $\begin{array}{l}\text { Reason for } \\
\text { application to } \\
\text { theumatology } \\
\text { department }\end{array}$ & $\begin{array}{l}\text { Consultation } \\
\text { indication }\end{array}$ & $\begin{array}{l}\text { Physical examination } \\
\text { findings }\end{array}$ & $\begin{array}{l}\text { Radiologic specific } \\
\text { findings }\end{array}$ & $\begin{array}{l}\text { Diagnosis } \\
\text { grouping }\end{array}$ & $\begin{array}{l}N \\
\text { di }\end{array}$ \\
\hline 9 & Boy & 6 & No & $\begin{array}{l}\text { Arthralgia } \\
\text { and arthritis }\end{array}$ & $\begin{array}{l}\text { Physical } \\
\text { examination and } \\
\text { radiologic } \\
\text { findings }\end{array}$ & $\begin{array}{l}\text { Short stature, arthritis } \\
\text { of right first } \\
\text { metacarpophalangeal } \\
\text { joint, and arthralgia } \\
\text { of left knee, both } \\
\text { ankles, elbows, and } \\
\text { neck }\end{array}$ & $\begin{array}{l}\text { Platyspondyly with } \\
\text { irregular vertebral } \\
\text { endplates, flattening } \\
\text { of the posterior } \\
\text { vertebral bodies, } \\
\text { metaphyseal changes } \\
\text { in the long bones, } \\
\text { enchondromatous } \\
\text { lesions in distal } \\
\text { radius and ulna, and } \\
\text { dense calcifications } \\
\text { in the basal ganglia }\end{array}$ & $\begin{array}{l}\text { Definite } \\
\text { clinical } \\
\text { and } \\
\text { molecular } \\
\text { diagnosis }\end{array}$ & $\begin{array}{l}\mathrm{H} \\
A \\
\mathrm{~m}\end{array}$ \\
\hline 10 & Girl & 16 & No & $\begin{array}{l}\text { Arthralgia } \\
\text { and arthritis }\end{array}$ & $\begin{array}{l}\text { Physical } \\
\text { examination and } \\
\text { radiologic } \\
\text { findings }\end{array}$ & $\begin{array}{l}\text { Short stature, } \\
\text { arthralgia, and } \\
\text { arthritis of bilateral } \\
\text { metacarpophalangeal } \\
\text { joints }\end{array}$ & $\begin{array}{l}\text { Metaphyseal changes } \\
\text { in the long bones, } \\
\text { platyspondyly in the } \\
\text { vertebral bodies, and } \\
\text { dense intracranial } \\
\text { calcifications }\end{array}$ & $\begin{array}{l}\text { Definite } \\
\text { clinical } \\
\text { and } \\
\text { molecular } \\
\text { diagnosis }\end{array}$ & $\begin{array}{l}\mathrm{H} \\
A \\
\mathrm{r}\end{array}$ \\
\hline 11 & Girl & 16 & $\begin{array}{l}\text { Yes } \\
\text { (1st degree } \\
\text { cousin } \\
\text { marriages) }\end{array}$ & $\begin{array}{l}\text { Malar rash, } \\
\text { fever, rash } \\
\text { and } \\
\text { arthralgia }\end{array}$ & $\begin{array}{l}\text { Physical } \\
\text { examination and } \\
\text { radiologic } \\
\text { findings }\end{array}$ & $\begin{array}{l}\text { Malar rash, arthralgia, } \\
\text { and short stature. }\end{array}$ & $\begin{array}{l}\text { Platyspondyly in } \\
\text { vertebra and } \\
\text { metaphyseal changes }\end{array}$ & $\begin{array}{l}\text { Definite } \\
\text { molecular } \\
\text { diagnosis }\end{array}$ & $\mathrm{N}$ \\
\hline
\end{tabular}

Eight patients are still under follow up in the genetic department with the strongly probable diagnosis of "Nonspecific connective tissue disorder". These patients were questioned in terms of hereditary connective tissue diseases (HCTD) because of the detection of the finding of joint hypermobility on physical examination. Accompanying clinical findings included easy bruising ( $\mathrm{n}: 3)$, pes planus ( $\mathrm{n}: 2)$, a history of spontaneous pneumothorax (n:1), cardiac defect ( $\mathrm{n}: 1)$ and striae $(\mathrm{n}: 1)$.

Direct radiography findings contributed to the diagnosis especially in six patients. Epiphyseal enlargement of the metacarpophalangeal and interphalangeal joints (patient 5), and enlarged epiphyses of the femoral heads, platyspondyly of vertebral bodies, anterior wedging of vertebrae, and erosion in the end plates (patients 6) were observed in patients with PPRD (Fig. 2). Radiologic examination of patient 4 revealed cone-shaped epiphyses that were highly suspicious for tricho-rhino-phalangeal syndrome (TRPS) (Fig. 3). In addition, in the radiological examination of the 9th, 10th and 11th patients, platyspondyly with irregular vertebral endplates, flattening of the posterior vertebral bodies, metaphyseal changes in the long bones, and enchondromatous lesions in distal radius and ulna were consistent with radiographic findings of SPENCD (Fig. 4).

\section{Discussion}

In this study a total of 60 patients who were initially admitted to the department of pediatric rheumatology but were thought to have associated genetic diseases were evaluated retrospectively. One third of patients $(n=19 / 60,31.6 \%)$ who were subsequently evaluated at the genetic department, were diagnosed with a genetic disorder. Considering that the diagnosis rate is very high, the threshold value should be kept low in terms of genetic diseases.

Non-rheumatic diseases are a substantial part of the pediatric rheumatology department referrals. As a result of a 3-year study conducted by the Pediatric Rheumatology Database Research Group in the United States, 12,939 patients recorded in the registry and over $50 \%$ of the patients had non-rheumatic diagnosis (10). Similarly, among 3269 patients who applied to the pediatric rheumatology department between 1981 and 2004 , a diagnosis was established in 2026 patients (61.9\%): The diagnosis were rheumatic diseases in 1032 (50.9\%) and non-rheumatic disease in 994 (49.1\%) of the patients (11). Distribution of nonrheumatic disease were orthopedic, mechanical or traumatic condition ( $\mathrm{n}: 345)$, infection ( $\mathrm{n}: 231)$, hematologic or neoplastic disease ( $\mathrm{n}: 45)$ and variety of other conditions (n:336). Genetic disease was present in 14 of 336 patients in the category of other conditions and most frequent of them (n:4) were HCTD. In our study, a total of 30432 patients applied to the pediatric rheumatology department over a period of 5 years. and among them, 60 were consulted to the genetic department. Of these 60 patients, a diagnosis of a genetic disorder could be established in 19 (31.6\%) of them. Hereditary connective tissue disorders represented the most common $(n=8 / 19,42.1 \%)$ diagnosis in our group.

Joint swelling, deformity in the extremity, arthralgia, and skin rash were the most of the symptoms for applying to the rheumatology department of consulted patients. We referred the patients to the genetic department due to the presence of skeletal anomalies, short stature, joint deformity, joint hyperlaxity, and dysmorphic findings, multiple anomalies, genetic diagnosis suspicion according to the results of radiological examination, and the lack of clinical and laboratory signs of inflammation. They has some common features of skeletal dysplasias such as short stature, ligamentous laxity, spinal deformity, progressive finger contractures, and extremity deformities $(12,13)$. Systemic physical examination, systemic findings, evaluation of growth and development, family history and concomitant diseases give an idea in terms of possible genetic disorders (14).

Radiologic examination has a crucial role in the diagnosis of rheumatologic diseases. Radiological imaging methods provide noninvasive information about the pathological processes developing in the musculoskeletal system, and helps the diagnosis. Six patients with definitive clinical diagnosis had direct radiography findings specific to the diagnosis in our study. Direct radiography which is the basic method of imaging provide a differential diagnosis as well as 
diagnosis of rheumatological diseases (15). According to European League against Rheumatism (EULAR)-Pediatric Rheumatology European Society (PReS) recommendations, direct radiography is recommended especially for the detection of structural abnormalities (16).

Genetic skeletal disorders can mimic juvenile idiopathic arthritis. Camptodactyly-arthropathy-coxa vara-pericarditis (CACP) syndrome (OMIM 208250) is a rare autosomal recessive disease characterised with early-onset camptodactyly, noninflammatory arthropathy, progressive coxa vara deformity and noninflammatory pericardial effusion. CACP is caused by homozygous mutation in the PRG4 gene (OMIM 604283) on chromosome 1q31 (17). PRG4 encodes the protein lubricin which is involved in the diffusive behavior of synovial fluid and contributes to the elastic absorption and energy dissipation of synovial fluid at physiologic shear frequencies (18). Joint findings of CACP syndrome may be confused with the joint findings of juvenile idiopathic arthritis (7). Many mutations have been identified in the PRG4 gene and new mutations continue to be identified (19). Diagnosis of CACP is based on clinical findings, radiologic and echocardiography findings. Genetic testing can confirm the diagnosis. However, the absence of a mutation does not exclude the diagnosis.

Another genetic skeletal disorder which may be confused with juvenile idiopathic arthritis is progressive pseudorheumatoid dysplasia (PPRD, OMIM 208230) which is an autosomal-recessive disease caused by mutations in the WISP3 (Wnt1-inducible signaling pathway protein 3, OMIM 603400) gene. Patients usually present with polyarticular involvement and gait abnormalities. Subsequently, involvement of the large joints and spine can accordingly cause severe joint contractures, hip disease and spinal deformities $(20,21)$. Swelling in the interfalengeal joints may be confused with polyarticular juvenile idiopathic arthritis, however inflammatory markers are normal and they do not respond to antirheumatic therapy (22). Numerous WISP3 mutations have been reported. However intronic mutations leading to splicing aberrations can only be extracted from cultured skin fibroblasts. As in our two cases, the absence of mutation in the WISP-3 gene does not rule out the diagnosis of PPRD without making cultured skin fibroblasts.

Tricho-Rhino-Phalangeal syndrome tip 1 (TRPS, OMIM 190350) is characterized craniofacial and skeletal abnormalities. The main findings are sparse, thin hair, bulbous nasal tip, short stature, cone-shaped epiphyses of the hands and feet which were present in our patient (23). Diagnosis of TRPS is frequently based on clinical and radiological findings since the phenotype is often evident (24). We reported a case with clinical and radiological features (especially cone-shaped epiphyses) that were highly suspicious for TRPS. A confirmatory genetic diagnosis was not available since we could not perform DNA sequence analysis.

Spondyloenchondrodysplasia (SPENCD, OMIM 607944) is a rare autosomal recessive skeletal dysplasia which is characterized with neurological involvement and immune dysfunction (25). SPENCD is an interferonopathy. SPENCD patients should be monitored for SLE and other comorbidities, while the possibility of SPENCD should be considered in SLE patients with short stature and skeletal abnormalities. Metaphyseal changes in the long bones and platyspondyly in the vertebral bodies are radiographic findings of SPENCD as seen all three of our patients as we reported before (26).

This study has some limitations. This study is for a selected group of patients who were initially referred to the department of pediatric rheumatology. Patients who were initially referred to the department of genetics who were not included in the study. Larger-scale and multi-center studies are needed. Despite this limitation, to our knowlegde, this study yet represents the first kind of its own evaluating the diagnostic profile of consulted patients in the literature.

\section{Conclusion}

In conclusion, in patients who apply to rheumatology outpatient clinics with musculoskeletal findings without inflammation, concomitant diseases should be considered. Summarizing the genetic diagnostic spectrum detected in these patients will hopefully increase the awareness of the physicians involved in patient care.

\section{Abbreviations}

CACP syndrome

Camptodactyly, arthropathy, coxa vara deformity and pericarditis syndrome

EULAR

European League against Rheumatism

HCTD

Hereditary connective tissue diseases

PPRD

Progressive pseudo rheumatoid dysplasia

PReS

Pediatric Rheumatology European Society

SPENCD

Spondyloenchondrodysplasia

TRPS

Tricho-rhino-phalangeal syndrome

\section{Declarations}

Financial Disclosure: The authors have indicated they have no financial relationships relevant to this article to disclose.

Funding Source: No external funding for this manuscript.

Loading [MathJax]/jax/output/CommonHTML/jax.js 
Conflict of Interest: The other authors have indicated they have no potential conflicts of interest to disclose

Clinical Trial Registration: Hacettepe University Ethics Commission (Approval number: G0 19/781)

\section{Acknowledgments}

Not Applicable.

\section{Authors' contributions}

UKA conceptualized and designed the study, drafted the initial manuscript, reviewed and revised the manuscript. POSK contributed to the data collection, study design and as well as approved the final manuscript as submitted. GUD conceptualized and designed the study, and approved the final manuscript as submitted. ES drafted the initial manuscript and conceptualized the study. EA designed the study and drafted the initial manuscript. GEU contributed to the data collection and drafted the initial manuscript. MA contributed to the data collection and approved the final manuscript as submitted. KB coordinated and supervised data collection, approved the final manuscript as submitted. YB designed the study, critically reviewed and revised the manuscript. SO coordinated and supervised data collection, and critically reviewed and revised the manuscript.

\section{Availability of data and materials}

All data generated or analyzed during this study are included in this published article.

\section{Consent for publication}

All authors give consent for publication.

\section{References}

1. Spencer $\mathrm{CH}$, Patwardhan A. Pediatric rheumatology for the primary care clinicians-recognizing patterns of disease. Current problems in pediatric and adolescent health care. 2015;45(7):185-206.

2. Calder AD, Foley P. Skeletal dysplasias: an overview. Paediatrics and Child Health. 2018;28(2):84-92.

3. Madhusudan S, Gupta A, Prakash M, Matta D, Suri D, Singh S. Camptodactyly-arthropathy-coxa vara-pericarditis (CACP) syndrome: a mimicker of juvenile idiopathic arthritis. Scand J Rheumatol. 2016;45:77 - 8.

4. Garcia Segarra N, Mittaz L, Campos-Xavier AB, Bartels CF, Tuysuz B, Alanay Y, et al., editors. The diagnostic challenge of progressive pseudorheumatoid dysplasia (PPRD): a review of clinical features, radiographic features, and WISP3 mutations in 63 affected individuals. American Journal of Medical Genetics Part C: Seminars in Medical Genetics; 2012: Wiley Online Library.

5. Albuhairan I, Al-Mayouf SM, editors. Camptodactyly-arthropathy-coxavara-pericarditis syndrome in Saudi Arabia: Clinical and molecular genetic findings in 22 patients. Seminars in arthritis and rheumatism; 2013: Elsevier.

6. Al-Mayouf SM. Noninflammatory disorders mimic juvenile idiopathic arthritis. International Journal of Pediatrics and Adolescent Medicine. 2018;5(1):1-4.

7. Offiah AC, Woo P, Prieur A-M, Hasson N, Hall CM. Camptodactyly-arthropathy-coxa vara-pericarditis syndrome versus juvenile idiopathic arthropathy. American Journal of Roentgenology. 2005;185(2):522-9.

8. Neyzi O, Bundak R, Gökçay G, Günöz H, Furman A, Darendeliler F, et al. Reference values for weight, height, head circumference, and body mass index in Turkish children. Journal of clinical research in pediatric endocrinology. 2015;7(4):280.

9. Kurt-Sukur ED, Simsek-Kiper PO, Utine GE, Boduroglu K, Alanay Y. Experience of a skeletal dysplasia registry in Turkey: A five-years retrospective analysis. American Journal of Medical Genetics Part A. 2015;167(9):2065-74.

10. Bowyer S, Roettcher P. Pediatric rheumatology clinic populations in the United States: results of a 3 year survey. Pediatric Rheumatology Database Research Group. The Journal of Rheumatology. 1996;23(11):1968-74.

11. Rosenberg AM. Longitudinal analysis of a pediatric rheumatology clinic population. The Journal of rheumatology. 2005;32(10):1992-2001.

12. Unger S. A genetic approach to the diagnosis of skeletal dysplasia. Clinical Orthopaedics and Related Research (1976-2007). 2002;401:32-8.

13. Brown R, Monsell F. Understanding the skeletal dysplasias. Current Orthopaedics. 2003;17(1):44-55.

14. Solomon BD, Muenke M. When to suspect a genetic syndrome. American family physician. 2012;86(9):826.

15. Matuszewska G, Zaniewicz-Kaniewska K, Włodkowska-Korytkowska M, Smorawińska P, Saied F, Kunisz W, et al. Radiological imaging in pediatric rheumatic diseases. Polish journal of radiology. 2014;79:51. 
16. Colebatch-Bourn A, Edwards C, Collado P, D'Agostino M, Hemke R, Jousse-Joulin S, et al. EULAR-PReS points to consider for the use of imaging in the diagnosis and management of juvenile idiopathic arthritis in clinical practice. Annals of the Rheumatic Diseases. 2015;74(11):1946-57.

17. Taşar M, Eyileten Z, Kasımzade F, Uçar T, Kendirli T, Uysalel A. Camptodactyly-arthropathy-coxa vara-pericarditis (CACP) syndrome. J Pediatr. 2014;56:6846.

18. Jay G, Torres J, Warman M, Laderer M, Breuer K. The role of lubricin in the mechanical behavior of synovial fluid. Proceedings of the National Academy of Sciences. 2007;104(15):6194-9.

19. Mannurita SC, Vignoli M, Bianchi L, Kondi A, Gerloni V, Breda L, et al. CACP syndrome: identification of five novel mutations and of the first case of UPD in the largest European cohort. European Journal of Human Genetics. 2014;22(2):197-201.

20. Pode-Shakked B, Vivante A, Barel O, Padeh S, Marek-Yagel D, Veber A, et al. Progressive Pseudorheumatoid Dysplasia resolved by whole exome sequencing: a novel mutation in WISP3 and review of the literature. BMC medical genetics. 2019;20(1):53.

21. Giray E, Yağcı İ, Elçioğlu HN. Progressive pseudorheumotoid dysplasia: A presentation of four cases with slow and rapid progression and effects of early rehabilitation program. Turkish journal of physical medicine and rehabilitation. 2019;65(3):290.

22. Adak B, Tekeoĝlu I, Sakarya M, Uĝra S. Progressive pseudorheumatoid chondrodysplasia: a hereditary disorder simulating rheumatoid arthritis. Clinical rheumatology. 1998;17(4):343-5.

23. Vaccaro M, Guarneri C, Blandino A. Trichorhinophalangeal syndrome. Journal of the American Academy of Dermatology. 2005;53(5):858 - 60.

24. Maas S, Shaw A, Bikker H, Hennekam RC. Trichorhinophalangeal syndrome. 2017.

25. Girschick H, Wolf C, Morbach H, Hertzberg C, Lee-Kirsch MA. Severe immune dysregulation with neurological impairment and minor bone changes in a child with spondyloenchondrodysplasia due to two novel mutations in the ACP5 gene. Pediatric Rheumatology. 2015;13(1):37.

26. Bilginer Y, Düzova A, Topaloğlu R, Batu E, Boduroğlu K, Güçer Ş, et al. Three cases of spondyloenchondrodysplasia (SPENCD) with systemic lupus erythematosus: a case series and review of the literature. Lupus. 2016;25(7):760-5.

$</$ ol

\section{Figures}

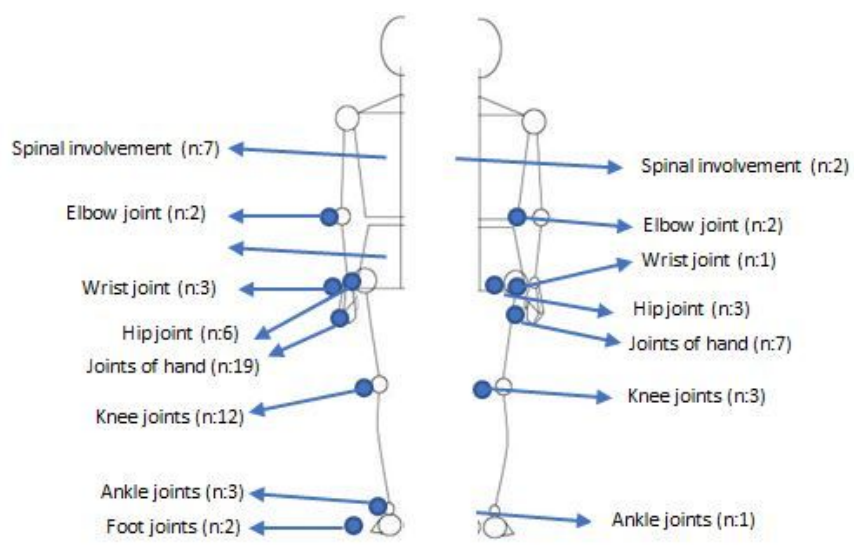

\section{Figure 1}

Distrubition of joint involvement (in all consulted patients on the left, in diagnosed with genetic disease on the right) 


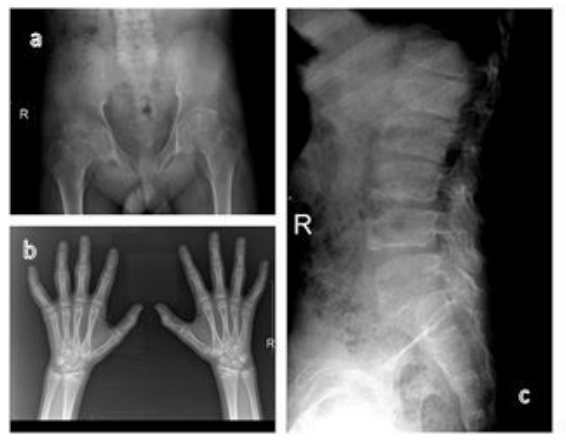

\section{Figure 2}

Radiological images of patients with PPRD (a: enlarged epiphyses of the femoral heads, b: epiphyseal enlargement of the metacarpophalangeal and interphalangeal joints, c: platyspondyly of vertebral bodies, anterior wedging of vertebrae, and erosion in the end plates)

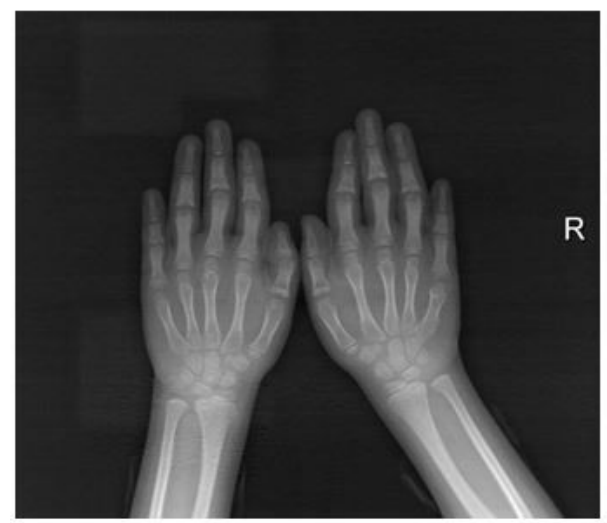

\section{Figure 3}

Patient 3: X-ray of the hands showing cone-shaped epiphyses of the 2 nd to 4 th middle phalanges

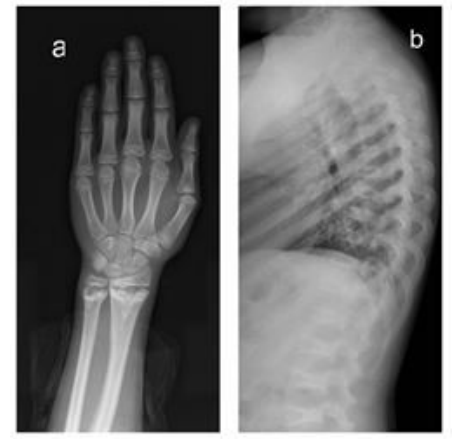

\section{Figure 4}

Radiological images of patients with SPENCD (a: metaphyseal changes in the long bones, b: platyspondyly with irregular vertebral endplates, flattening of the posterior vertebral bodies) 